\title{
FALL 2019
}

\section{The}

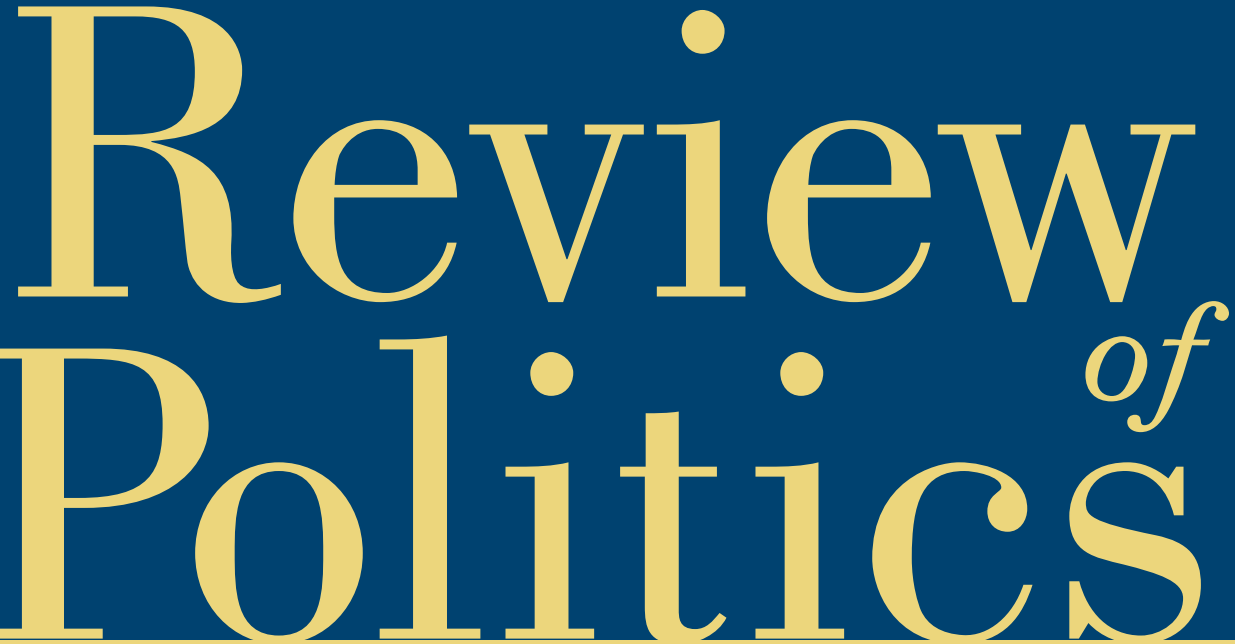

ARTICLES

Eric Cheng, "Aristotelian Realism: Political Friendship and the Problem of Stability"

Alexandra Oprea, "Pluralism and the General Will: The Roman and Spartan Models in Rousseau's Social Contract"

Kevin D. Pham, "Phan Chu Trinh's Democratic Confucianism" William Bosworth and Keith Dowding, "The Cambridge School and Kripke: Bug Detecting with the History of Political Thought"

SYMPOSIUM

Melissa S. Williams, Micah Schwartzman, Lori Watson, Mark Storslee, and Avia Pasternak on Cécile Laborde's Liberalism's Religion, with a response by Cécile Laborde

Review Essay: Jeffrey R. Collins, "The Lost Historiography of Liberalism" 


\title{
THE REVIEW OF POLITICS
}

\author{
Editor \\ RUTH ABBEY \\ Book Review Editor \\ SUSAN D. COLLINS \\ Interim Book Review Editor \\ MARY M. KEYS \\ Editorial Coordinator \\ KELLI BROWN
}

Editorial Board

\author{
Pierre Manent \\ L'Ecole des Hautes Etudes en \\ sciences sociales \\ Harvey C. Mansfield \\ Harvard University \\ A. James McAdams \\ University of Notre Dame \\ Daniel Philpott \\ University of Notre Dame \\ Arlene Saxonhouse \\ University of Michigan \\ William E. Scheuerman \\ Indiana University, Bloomington \\ John T. Scott \\ University of California, Davis \\ Steven B. Smith \\ Yale University \\ Peter Steinberger \\ Reed College \\ Vickie Sullivan \\ Tufts University \\ Jean M. Yarbrough \\ Bowdoin College
}

\section{Copyeditor: LES HARRIS}

Editorial Interns: Alejandro Castrillon and Tyler Thomas

Former Editors

Waldemar Gurian

M.A. Fitzsimons

Donald P. Kommers

Thomas Stritch

Walter Nicgorski

Frederick J. Crosson

Catherine Zuckert

The Review of Politics publishes primarily philosophical and historical studies of politics, especially those in political theory and American political thought. The journal also includes thoughtful scholarly reflections on all aspects of politics-laws, and institutions, international relations, comparative politics-as well as literary reflections on politics or political interpretations of literature. 


\section{TABLE OF CONTENTS FALL 2019}

Vol. 81

FALL 2019

No. 4

Eric Cheng

Aristotelian Realism: Political Friendship and the

Problem of Stability . . . . . . . . . . . . . . . . . . . . . 549

Alexandra Oprea

Pluralism and the General Will: The Roman and

Spartan Models in Rousseau's Social Contract . . . . . . . . . . 573

Kevin D. Pham

Phan Chu Trinh's Democratic Confucianism . . . . . . . . . 597

William Bosworth and Keith Dowding

The Cambridge School and Kripke: Bug Detecting with the

History of Political Thought . . . . . . . . . . . . . . 621

Symposium:

Melissa S. Williams, Micah Schwartzman, Lori Watson, Mark Storslee, and Avia Pasternak on Cécile Laborde's Liberalism's Religion, with

a response by Cécile Laborde . . . . . . . . . . . . . . . . . . . . . . . 643

Review Essay:

Jeffrey R. Collins

The Lost Historiography of Liberalism

Reviews:

Jeremy Reid

Review of Joshua I. Weinstein's Plato's Threefold City and Soul . . . . .689

Andreas Avgousti

Review of Jonny Thakkar's Plato as Critical Theorist . . . . . . . . . . . .691

Douglas Kries

Review of Maxwell A. Cameron's Political Institutions and Practical

Wisdom: Between Rules and Practice . . . . . . . . . . . . . . . . . . . .695

Stephen Patrick Sims

Review of Gregory Bruce Smith's Political Philosophy and the

Republican Future: Reconsidering Cicero

Pamela K. Jensen

Review of Mark Kremer's Romanticism and Civilization: Love,

Marriage, and Family in Rousseau's "Julie" . . . . . . . . . . . . . . . . .700

Kuangyu Zhao

Review of James T. Schleifer's Tocqueville . . . . . . . . . . . . . . .703

Sid Simpson

Review of Antonio Negri's Marx and Foucault: Essays . . . . . . . . . . 706 
Michael E. Zimmerman

Review of Ronald Beiner's Dangerous Minds: Nietzsche, Heidegger, and the Return of the Far Right . . . . . . . . . . . . . . . . . . . . . . .709

Frédéric Krumbein

Review of Hans Ingvar Roth's P. C. Chang and the Universal

Declaration of Human Rights . . . . . . . . . . . . . . . . . .711

Nasser Behnegar

Review of J. A. Colen and Svetozar Minkov's Toward "Natural

Right and History": Lectures and Essays by Leo Strauss, 1937-1946 . . . .714

John von Heyking

Review of Danny Kaplan's The Nation and the Promise of Friendship:

Building Solidarity through Sociability. . . . . . . . . . . . . . . . . . .718

Mark Hoipkemier

Review of Abraham A. Singer's The Form of the Firm: A Normative

Political Theory of the Corporation. . . . . . . . . . . . . . . . . . . .722

Emily McGill

Review of Lori Watson and Christie Hartley's Equal Citizenship and

Public Reason: A Feminist Political Liberalism . . . . . . . . . . . . . . . . . . . .724

Andrew Lambert

Review of Sungmoon Kim's Democracy after Virtue: Toward

Pragmatic Confucian Democracy . . . . . . . . . . . . . . . . . . . . . . .727

Hugo Drochon

Review of Laurence Lampert's What a Philosopher Is: Becoming

Nietzsche . . . ...........................730

Mark Frisch

Review of Alejandra M. Salinas's Liberty, Individuality, and

Democracy in Jorge Luis Borges. . . . . . . . . . . . . . . . . . . . . . . . . .732

List of Referees . . . . . . . . . . . . . . . . . . . 735 
Subscription Information: The Review of Politics (ISSN 0034-6705) is published quarterly in February, May, August and November by Cambridge University Press, One Liberty Plaza, 20th Floor, New York, NY 10006, USA/University Printing House, Shaftesbury Road, Cambridge CB2 8BS, UK for the University of Notre Dame. Annual subscription rates for Volume 81 (2019): Institutional subscription rates, print and online: US $\$ 218.00$ in the USA, Canada, and Mexico; UK $£ 128.00$ + VAT elsewhere. Institutional subscription rates, online only: US $\$ 180.00$ in the USA, Canada, and Mexico; UK $£ 110.00$ + VAT elsewhere. Institutional subscription rates, print only: US \$207.00 in the USA, Canada, and Mexico; UK $£ 125.00$ + VAT elsewhere. Individual subscription rates, print only: US $\$ 51.00$ in the USA, Canada, and Mexico; UK $£ 29.00+$ VAT elsewhere. Single part rates: US $\$ 60.00$ in the USA, Canada, and Mexico; UK $£ 36.00$ Correspondence concerning subscriptions should be sent to: Cambridge University Press, One Liberty Plaza, 20th Floor, New York, NY 10006, USA for customers in the USA, Canada, or Mexico. Customers elsewhere should contact: Cambridge University Press, University Printing House, Shaftesbury Road, Cambridge CB2 8BS, UK.

Editorial Office: All correspondence concerning submissions and manuscripts under review should be sent to The Review of Politics, University of Notre Dame, 2005 Jenkins Nanovic Halls, Notre Dame, IN 46556-7000. Phone: 574-631-6623. Email: ROP.Editor.1@nd.edu. Website: reviewofpolitics.nd.edu

Abstracting and Indexing Information: Articles in The Review of Politics are indexed in the International Index to Periodicals and the Catholic Periodicals and Literature Index; abstracted in the International Political Science Abstracts; and abstracted and indexed in ABC POL. SCI., Historical Abstracts, Social Science Index (also available in the electronic versions), Book Review Index, and International Bibliography of the Social Sciences.

Copyright (C) 2019 University of Notre Dame. All rights reserved. No part of this publication may be reproduced, in any form or by any means, electronic, photocopy, or otherwise, without permission in writing from Cambridge University Press, Rights and Permissions Manager, One Liberty Plaza, 20th Floor, New York, NY 10006, USA. For further information see http://us.cambridge/org/information/rights/

Periodicals postage paid in New York, NY and additional mailing offices. Postmaster: Send address changes to The Review of Politics, Cambridge University Press, One Liberty Plaza, 20th Floor, New York, NY 10006, USA.

Photocopying information for users in the U.S.A.: the Item-Fee Code for the publication (0034-6705/18 \$9.00 +.10) indicates that copying for internal or personal use beyond that permitted by Sec. 107 or 108 of the U.S. Copyright Law is authorized for users duly registered with the Copyright Clearance Center (CCC) provided that the appropriate remittance of $\$ 9.00$ per article is paid directly to CCC, 222 Rosewood Drive, Danvers, MA 01923. Specific written permission must be obtained for all other copying. 